\title{
DỨcin
}

Technological University Dublin ARROW@TU Dublin

2000-01-01

\section{The Victimization of Juvenile Prostitutes in Ethiopia}

\author{
Kevin Lalor \\ Technological University Dublin, kevin.lalor@tudublin.ie
}

Follow this and additional works at: https://arrow.tudublin.ie/aaschsslarts

Part of the Criminology Commons, International and Area Studies Commons, and the Psychology Commons

\section{Recommended Citation}

Lalor, K.: The Victimisation of Juvenile Prostitutes in Ethiopia, International Social Work Vol 43 (2),pp.

227-242. doi:10.1177/002087280004300208

This Article is brought to you for free and open access by the Social Sciences at ARROW@TU Dublin. It has been accepted for inclusion in Articles by an authorized administrator of ARROW@TU Dublin. For more information, please contact arrow.admin@tudublin.ie, aisling.coyne@tudublin.ie,gerard.connolly@tudublin.ie.

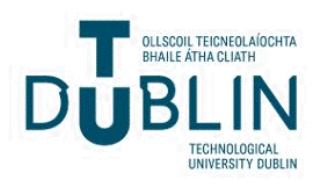




\section{The Victimisation of Juvenile Prostitutes in Ethiopia.}

Author: $\quad$ Dr. Kevin J. Lalor

Address: Dublin Institute of Technology, School of Social Sciences, 143-149 Lr. Rathmines Road, Dublin 6, Ireland.

Tel.: $\quad 01-4023523$

Fax: $\quad$ 01-4023499

e-mail: $\quad$ kevin.lalor@dit.ie

Running title: Victimisation of juvenile prostitutes.

Key words: Ethiopia; juvenile prostitution; victimisation.

\section{The Victimisation of Juvenile Prostitutes in Ethiopia}

\section{INTRODUCTION}

Recent years have seen an increase in concern for the welfare of juvenile prostitutes, particularly in the Southeast Asia region (for example, Truong, 1990; Ireland, 1993; O’Grady, 1993; Nyland, 1995; O’Connell Davidson \& Sachez Taylor, 1996). In response to the "sex-tourism" industry, organisations such as ECPAT (End Child Prostitution in Asian Tourism) and Preda (International Campaign Against the Sexual Exploitation of Children) have succeeded in bringing about legislative change in Australia, the United States and a number of European countries. These new laws will allow those who commit sexual offences against juveniles in countries such as Thailand and the Philippines to be prosecuted in their home countries.

However, in spite of this concern for the welfare of juvenile prostitutes, relatively little is known about the nature and incidence of abuse experienced by juvenile prostitutes in a developing world context. It is commonly assumed that juvenile prostitutes are a particularly abused and mistreated group, yet this assumption 
is rarely quantified in the literature. Consequently, the justifications for this research are twofold. Firstly, to quantify in an empirical manner the extent of the victimisation experienced by a sample of 30 juveniles engaged in prostitution. By examining this issue in detail, it is hoped that a more comprehensive portrait of the nature of abuse experienced by street girls might be penned, rather than the anecdotal, vignette-type descriptions more frequently found in the literature. Secondly, to highlight the victimisation of juvenile prostitutes in an African context. Heretofore, the plight of adolescents involved in prostitution has been well documented in the US (the Enablers, 1978; Bracey, 1979; Silbert, 1980; and Weisberg, 1985). More recently, as we have noted, this issue has received attention in South East Asia. Lucchini (1994) has examined the issue of street girls involved in prostitution in Brazil. However, in spite of the growing numbers of street children in Africa (Agnelli, 1986; Taçon, 1992), minimal research has been conducted into the victimisation of African street children in general, and juvenile prostitutes in particular. A comparison between a sample of African (Ethiopian) street children and their Latin American counterparts has been detailed elsewhere (Lalor, forthcoming). The purpose of this study is to survey the victimisation experienced by a sample of female juvenile prostitutes in Addis Ababa, Ethiopia.

\section{LITERATURE REVIEW}

\section{What is juvenile prostitution?}

"Child prostitution" is a term frequently used for prostitution involving a minor. However, pre-pubescent prostitutes would appear to be relatively rare. Weisberg (1985) concluded from a review of the research in the US that most juvenile prostitutes are older adolescents (aged fifteen to seventeen years) and that few adolescent female prostitutes are under fourteen. Ennew (1986, p. 83), too, reported 
that sexual exploitation of pre-pubescent children world-wide is rare. Even in Thailand, famed for its sex tourism and home of an estimated one million prostitutes, only an estimated $10 \%$ of prostitutes are aged fourteen years or younger (Ennew, 1986, p. 111). World-wide, the development of secondary sexual characteristics in prostitutes would appear to be a requirement for most clients.

Lucchini (1994) objects to the term "child prostitution." When referring to children between the ages of ten and twelve, he argues that it is an "abuse of classification" to refer to them as professional prostitutes as they are not capable of realising the high levels of exploitation they experience, nor possible alternative lifestyles. Instead, he prefers to label such children as "victims of sexual abuse." The distinction between "professional" and "victim" is important to make as it illustrates the lack of choice for younger children. It confronts the supposition that young children, because they are exposed to the harshness of prostitution and street life, are in some way adult-like and are able to make rational, informed decisions about their lifestyle and their sexuality. The label "prostitute" implies an individual making a choice, however limited, to engage in survival sex. Pre-pubescent children, argues Lucchini, are not in a position to make this choice. Thus, we can argue that the term "child prostitution" is a misnomer. Apart from the fact that it is very rare for clients to favour pre-pubescent children (as distinct from very young adolescents), when contractual sex takes place between a client and a pre-pubescent child it is more accurate to understand it, not as prostitution, but as child sexual abuse. 
A further initial consideration must be to question the demand for prostitutes who are clearly only in the early stages of puberty. That is, why are juvenile prostitutes attractive to some customers?

Firstly, there is undoubtedly a market in developing countries for juvenile sex that is created by Western paedophiles. The existence of local customs such as child brides may reinforce Western paedophilic rationalisations that "It's normal here". Of course, the distinction that such traditional marriages usually take place within an appropriate cultural context, with due regard to the needs of both partners and their families, is lost on such sexual predators.

Secondly, Aids has become widespread among the prostitute population in many developing countries, particularly in Africa. With this in mind, clients may reason that the young girl, who has spent less time on the streets, is less likely to have acquired the HIV virus. O'Grady (1993) attributed the "sudden burst in the number of child prostitutes" in Thailand to a fear of Aids among clients:

"Brothel workers claim that their customers are particularly anxious to have a prostitute who 'looks healthy.' Since young children usually convey a stronger

sense of being healthy than older jaded prostitutes, the demand for their services is increasing at all brothels. Many massage parlours in Thailand now have a separate room at the back where selected customers can be taken to view young girls, some as young as ten and eleven years, whose health is guaranteed and whose price is accordingly higher" (O'Grady, 1993, p. 43). 
However, the reality is that sex between a young child and an adult is more likely to transmit the HIV virus than sex between two adults as the blood tissues lining the male child's anus and rectum and the young girl's vagina are thin and easy to rupture. The younger prostitute being used by several customers a day ends up with internal injuries such as bleeding and abrasions that never have a chance to heal. There will be many open sores through which the HIV virus can easily pass (O'Grady, 1993). Ireland (1993) and Muntarbhorn (1992) also made this point.

Thirdly, in many developing countries child prostitutes are at the bottom end of the market, in terms of prices. Particularly among the urban poor in developing countries, the juvenile prostitute will be the only type of prostitute affordable to impoverished youths and men:

“These customers are not usually rich degenerates but poor, unemployed, and possibly homeless men. The attraction of children may be simply that they are the only sexual partners available to men who appear to be social failures and that the child's social status and small size provide a means of exercising power which is other wise not available to them" (Ennew, 1986, p. 83).

\section{The Victimisation of Juvenile Prostitutes}

We must turn to the developed world to find a comprehensive account of the lives of juvenile prostitutes. For example, Bracey's survey of 32 New York juvenile prostitutes (1979); the Enabler's study of 32 juvenile prostitutes in Minnesota (1978); Silbert's (1980) investigation into the sexual assaults experienced by 200 prostitutes, $70 \%$ of whom were under 21 years, in the San Francisco Bay area; and James's (1980) 
study of factors which initiate young girls into prostitution. A review of these and other studies is to be found in Weisberg (1985).

These studies reported that pimps and customers are the most frequent abusers of juvenile prostitutes in the United States. For example, Silbert (1980) reported that $66 \%$ of her sample experienced physical abuse by pimps. Fifty per cent of them were beaten "regularly" or "constantly." The reasons for this violence included disrespect, failure to earn enough money, departure or threatened departure and expressions of jealousy (Weisberg, 1985). Bracey's (1979) sample (n=32) reported abuse from sadistic or "kinky" customers who resorted to violence when a girl refused to perform certain acts. Similarly, 70\% of Silbert's (1980) sample were victimised by customer rape or clients going beyond the work contract. Seventy eight per cent of these sexual assault victims reported being assaulted by forced perversion an average of seventeen times per prostitute. The effects of these assaults were described as both physical and psychological:

"In $63 \%$ of the cases victims had bodily injuries serious enough to require repeated medical attention; in $13 \%$ they had broken bones; in $22 \%$ they suffered medical shock ... Every victim reported that the rape had a negative effect on their feelings towards men and toward themselves; the vast majority reported that the rape had a negative effect on their feelings towards sex; and more than half felt the rape had a negative impact on their attitudes toward emotional relationships and even friendships" (Silbert, 1980, p. 17).

Juvenile prostitutes also experience disproportionately high levels of pregnancy and sexually transmitted diseases, compared to adult prostitutes. Juveniles 
are typically less informed about the risks of venereal diseases and genital hygiene. Weisberg (1985) reported high levels of ignorance of sexuality, contraception and venereal disease among juvenile prostitutes:

"More than one quarter of juvenile prostitutes take no precautions against venereal disease, such as examining the customer or using condoms. The remainder use condoms for protection, but only some of the time. Also, some juvenile prostitutes do not know what an orgasm is or even that it is part of the sexual experience ... More than one fifth of juvenile prostitutes fail to take any precautions against pregnancy" (Weisberg, 1985, p. 114).

The result of this ignorance is high levels of pregnancy and venereal disease. The Enablers $(1978, n=52)$ reported that half of the sample had been pregnant at least once and almost one fifth had been pregnant more than twice. Silbert (1980) reported that $63 \%$ of her sample of 200 prostitutes (the majority, $68 \%$, being under sixteen) had been pregnant. James (1980) found the average age at first pregnancy to be 14.5 years. A further consequence of juvenile prostitution, reported by Silbert (1980), is that girls become ambivalent or neutral about sex. They neither like it nor dislike it, but view it only as a way of making money. Although adult prostitutes are sometimes reported as neutral toward sex with a customer but positive with a boyfriend, juveniles seem to be consistently neutral about sex (Bracey, 1979). Another effect is a general mistrust of people, especially men, of whom they become frightened (Enablers, 1978). Not surprisingly, Gibson-Ainyette, Templer, Brown and Veaco (1988) reported that a sample of 43 juvenile prostitutes "appear to have more depression and anxiety, more deviant life-style and alienation, and a less favourable self-concept" 
than a control group of delinquent and normal females (Gibson-Ainyette et al., 1988, p. 436). Seng (1989) reported that $83 \%$ of a sample of 35 juvenile prostitutes in Chicago were depressed, $78 \%$ were potentially suicidal and $86 \%$ had a poor self image, as judged by staff at a temporary shelter care facility.

In summary, the types of abuse most frequently reported by juvenile prostitutes are physical and sexual abuse from clients and pimps. Juvenile prostitutes also experience ill health due to unwanted pregnancies and exposure to contagious diseases. Psychological consequences are reported as lowered self-esteem, feelings of shame and guilt, social stigma and lack of future opportunities.

\section{Juvenile Prostitution in Addis Ababa}

Prostitution is widespread in Addis Ababa. Mehret, Khodakevich, Shanko, \& Belete (1990) estimated that $7.1 \%$ of the adult female population of Addis Ababa regularly practised multi-partner sexual contacts, the majority of these being prostitute-client contacts. As large as this figure is, it is likely to be an underestimation of the total number of females involved in prostitution as the sample does not include those under eighteen years of age. Ethiopia differs from other developing countries known to have large numbers of juvenile prostitutes, such as Thailand or the Philippines, because prostitution would not appear to be intrinsically linked to tourism. The long running civil war, which finally ended in 1991, on-going unrest and a poor infrastructure serves to keep all but the most intrepid tourists away. The clients of Ethiopian prostitutes are predominantly Ethiopian. Mehret et al.'s (1990) survey of 2,663 prostitutes in Addis Ababa found that only 2.3\% reported sexual contact with foreigners. There are few pimps, as we know it in Addis Ababa. 
Instead, girls typically wait for customers on the streets or in bars. The owners rarely employ "Bar-girls". Instead, they help the owner to serve drink and are free to solicit for customers. Some bars have rooms attached where a prostitute can bring her client. A third type of prostitute works from a house where a number of prostitutes rent rooms. Drink is sometimes served at such houses (Mehret et al., 1990). For the most part, prostitution in Addis Ababa is not a glamorous affair. Apart from some dozen night-spots frequented by foreigners, and the streets near the Hilton Hotel, the prostitutes are not dressed in the stereotypically provocative manner associated with prostitutes in the West. Instead, they are ordinarily dressed girls and women standing on the streets or working in the bars. Indeed, many of them are dressed in rags. Such girls can command as little as 40 US cents for their services.

Baardon's (1993) survey of 77 juvenile prostitutes in Addis Ababa found the mean age at starting prostitution was 14.7 years. Nineteen and a half per cent of the total sample were 12 years or younger when they entered prostitution. Extreme poverty was the major motivating factor for initiation into prostitution. Few of the girls could be described as full-time prostitutes. The majority had attempted to support themselves in some way prior to their entry into prostitution. Fifty one per cent had been housemaids, $23 \%$ had a petty trade and $11 \%$ had begged. Each of these occupations provided a living at subsistence level only: "It seems clear that the majority of girls do not regard prostitution as a first option. Rather, it is the last resort, but it is the one that brings them economic rewards which they never could realise through being a maid or a petty trader" (Baardson, 1993, p. 26).

With regard to victimisation, only $13 \%$ of Baardson's sample reported that they had not been raped, sexually abused or physically assaulted by customers. The most common reasons given for being assaulted were that the girls refused to engage 
in "deviant practices". Specifically, anal or oral sex. This abhorrence of any form of sexual contact other than peno-vaginal is also true of adult prostitutes in Addis Ababa. In a 1989 survey of 2,663 randomly selected female sex-workers, $98.1 \%$ reported practising peno-vaginal sex only, $1.7 \%$ in addition occasionally practised peno-rectal sex and 0.2\% peno-oral sex (Mehret et al., 1990).

\section{METHODOLOGY}

Sample. Thirty prostitutes between the ages of 14 and 18 were interviewed in Addis Ababa, Ethiopia in the period 1992-1993. The sample varied in their degree of involvement in prostitution. Some were full time prostitutes, others practised prostitution only occasionally and some had ceased prostitution altogether. Indeed, a point of contact for a small number of interviewees was a residential rehabilitation unit for ex-prostitutes.

Data collection. The data in this paper was extracted from a larger study detailing the nature and incidence of victimisation amongst street children (Lalor, 1997a). Groups of three or four girls were gathered at a safe, non-threatening location (a Save the Children-USA drop-in centre for street children). Peer support dictated that the girls be interviewed (using a translator) in turn, whilst remaining together as a group. This process has been described in Lalor (1997b).

The questionnaire. A victim survey questionnaire was used. Interviewees were questioned regarding their experiences of street life. They were asked about their experiences of being beaten, stolen from and sexually assaulted. They were further questioned regarding their experiences of pregnancy, abortion and contraception. The questionnaire took between 45 minutes and one hour to complete. 


\section{RESULTS}

\section{Age at initiation to prostitution}

Juvenile prostitutes in Addis Ababa $(\mathrm{n}=30)$ reported first prostituting themselves between the ages of 10 and 17. The average age of initiation was 13.9 years. Eleven girls began prostitution at the age of thirteen or younger. Three girls began prostituting themselves at the age of twelve or younger.

\section{Degree of involvement in prostitution}

Approximately half (14) of the sample engaged in prostitution only occasionally. Otherwise they earned their money through begging or peddling. Whilst recognising the greater earning potential of prostitution, these girls reported that fear of disease, pregnancy and abuse by "strange men" prevented them from becoming more permanently involved in prostitution. They resorted to prostitution only when they were very short of money; otherwise they preferred to beg. The remaining 16 girls cited prostitution as their full-time occupation.

\section{Victimisation of Juvenile Prostitutes in Addis Ababa}

Rape: Twenty two (73\%) of this sample have been raped at least once and a further four girls experienced sexual assaults which did not result in completed rapes, due to the girl's successful resistance. Five interviewees were raped once, 11 were raped once and have been sexually attacked several times, one has been raped twice, two have been raped three times, two were raped "often" or "several" times and one girl has been raped seven times. The details of twenty-six rapes were reported:

\begin{tabular}{|l|l|}
\hline Description & $\begin{array}{l}\text { Number and \% of interviewees } \\
\text { experiencing this type of rape }\end{array}$ \\
\hline $\begin{array}{l}\text { A group of boys took her by force to a dark/quiet area } \\
\text { and a number of them raped her }\end{array}$ & $14(47 \%)$ \\
\hline A single man forced the girl, usually by knife-point, & $6(20 \%)$ \\
\hline
\end{tabular}




\begin{tabular}{|l|l|}
\hline to a quiet area or hotel and raped her & \\
\hline $\begin{array}{l}\text { A client pretended to be alone and took the girl to a } \\
\text { hotel room where his friends were waiting and she } \\
\text { was raped }\end{array}$ & $3(10 \%)$ \\
\hline $\begin{array}{l}\text { A client refused to pay, the girl tried to leave, but was } \\
\text { raped }\end{array}$ & $2(7 \%)$ \\
\hline $\begin{array}{l}\text { Girl was drugged by an old woman who then invited } \\
\text { boys to come and pay to rape her }\end{array}$ & $1(3 \%)$ \\
\hline
\end{tabular}

Table 1: The types of rape experienced by juvenile prostitutes in Addis

\section{Ababa.}

As we can see, 17 of these rape episodes involved more than one man/boy. In total, $15(50 \%)$ of the sample have been the victims of group rapes.

Pregnancy: Eleven (37\%) of the sample have been pregnant. The average age at which interviewees became pregnant was 14.9 years. Eight of these pregnancies were the result of prostitution, one was the result of a rape, one occurred in a traditional early marriage and one pregnancy was the result of a relationship with a boy friend. Of these eleven girls, six have had abortions at least once.

Outcomes of pregnancies: (This total is greater than the number of girls who have been pregnant as three girls have been pregnant more than once). Two babies were carried to full term and were living with their mothers by begging on the streets. At the time of interviewing, these children were two and four years of age respectively. Two of the girls were heavily pregnant at the time of interviewing. One baby died at four months from an intestinal disease and another baby died from cold one month and ten days after birth. One child was born at seven months after the mother had been beaten on the streets. The hospital said they would keep the baby, as the mother was unable to care for it. The mother suspected that the child had in fact been still born. Six girls have ended their pregnancies by abortion at least once (one girl has had three abortions). The most common technique for abortion was to drink a concoction made by old women that contained a ground leaf of some kind boiled in 
water. This drink had the effect of making the girl violently sick. One girl reported drinking a soft drink mixed with ampicillin tablets. Finally, one girl claimed to have had her abortion by placing a piece of plastic on a string into her uterus and leaving it there for three days. When it was removed, a miscarriage occurred.

Contraception: Fifteen, or half, of the sample use a contraceptive device. Twelve use condoms and a further three use a contraceptive pill. Twelve girls reported that they use no contraception at all (three girls failed to answer this question). Of these, two girls reported that they did not know how to use condoms; one believed that chewing khat (a mild narcotic leaf) would protect her from pregnancy; and a further two believed that having multiple partners made pregnancy impossible. The remainder claimed that they did not like condoms, that they placed their trust in God or that their clients would not let them use condoms.

Beatings: Twenty-eight (93\%) of the sample have been beaten whilst working on the streets. The perpetrators of these beatings were usually boys and men the girls encountered whilst working on the streets. Twenty of the girls were beaten at least once (usually several times) by deriyeas (delinquents) when they refused to provide sexual services free of charge or when they resisted a man's attempts to rape them. We might consider such episodes to be "attempted sexual assaults." The next most frequently cited reason for being beaten by men/boys on the streets was robbery, reported by 12 girls. The customers of prostitutes are a significant source of victimisation. Five girls reported being beaten when they protested that they were not paid the agreed price or were not paid at all. Four were beaten into submission when they refused to perform "un-natural" acts or positions. Four prostitutes were beaten by their clients when they were caught trying to steal from them, or cheat them. Other reasons given for being beaten by clients were for refusing to allow a client have 
intercourse more than the agreed single time and one girl reported being beaten by her client "just for fun." Ten girls reported being beaten by the police or soldiers for begging, peddling or causing disturbances. Two reported being beaten by a soldier and a policeman respectively for not consenting to free sex.

Eight girls reported being beaten by ordinary passers-by on the streets. Men who were disapproving of the girl's lifestyle hit five of these girls. Other girls reported being commonly spat upon and insulted because they were begging rather than working. Three girls were beaten by passers-by that took offence at being solicited by a prostitute.

Theft: Twenty-five (83\%) of the sample have had things stolen from them whilst living on the streets. The most frequently stolen items (reported by nineteen girls) were clothes, shoes or blankets. These are often stolen while the girl sleeps (either outside on the "verandas" or indoors in rented rooms which are shared with large numbers of other street children), usually by other girls. Most interviewees reported that they were particularly susceptible to this form of theft when they were new to the streets and were not yet wary enough of their personal possessions. The next most common form of theft, reported by eight girls, is non-payment or underpayment from clients. Seven girls reported having had money stolen from them by street boys. Such thefts were frequently accompanied by threatened or actual violence. In fact, a small number of interviewees had severe scarring from such assaults. 
Juvenile prostitution in Addis Ababa is primarily a symptom of poverty.

Consequently, it is unrealistic to think of its eradication. However, this research has implications for policy and practice which may alleviate the most acute manifestations of this societal disorder.

Prior to the second half of 1993, no Non Governmental Organisation (NGO) offered residential facilities for street girls in Addis Ababa. Night time is when girls are most likely to be victimised. For girls who cannot afford the price of rented accommodation, it is vital that they have somewhere safe to spend the night. Two such units opened in the latter half of 1993. The smaller of the two provided a full residential and training service specifically to ex-juvenile prostitutes. Ten girls and three of their babies were housed in this unit which, unfortunately, closed down a short time later. The larger unit continues to provide sleeping space for street girls in a hall which doubles as a street child resource centre during the day. This is an invaluable facility for street girls to be able to avail of in order to avoid sexual victimisation. Addis Ababa needs more secure sleeping spaces for both street boys and street girls. These need not necessarily be run in conjunction with rehabilitative, vocational or educational services. The primary need is for children to be off the streets come night fall.

Local government in Addis Ababa appears to have been responsible for making a number of interviewees homeless. The kebele, which is the smallest administrative unit of the government, provides cheap rented accommodation as part of its range of services for the urban poor. However, upon the death of the rent payer it would appear that this service is not extended to his or her dependants. A small number of 
interviewees reported having been made homeless in this way. That is, upon the death of their mothers they were forced to leave their homes. No provisions were made for alternative accommodation. Even the poorest of kebeles have a community hall. The majority of these lie empty each night, apart from a watchman. These halls should be made available to children who have nowhere else to sleep. There is a large market for cheap rented accommodation. At present, this gap in the market is met by landlords who provide filthy and sub-standard accommodation, thus exploiting homeless children. Local government, by way of local kebele committees, could provide a free, clean, safe, healthy alternative. A small number of kebeles already provide such a service on an informal, temporary basis. Such arrangements seem to operate with a minimum of disruption if the street children involved are adequately screened. This is a service which all kebeles might offer.

Ignorance regarding reproduction and the transmission of disease is widespread among Addis Ababa's juvenile prostitutes. For example, reported methods of avoiding pregnancy included having multiple partners and eating chilli peppers. The high incidence of Aids amongst prostitutes (Baardson, 1993), does not appear to have led to the widespread use of precautionary strategies by juvenile prostitutes, or indeed by some of their clients. Forty per cent of this sample do not use condoms. Not surprisingly, recent estimates suggest a $25 \%$ incidence of HIV amongst street prostitutes (it is thought to be even higher (50\%) for "bar-ladies"). A majority of street children have a modicum of knowledge of Aids. Radio was the most commonly cited source of information, with others naming television, school, friends and the church. Few specifically mentioned condoms but most knew that Aids is incurable and the best form of prevention is to have only one sexual partner. Given 
this widespread basic knowledge of Aids, why do so few juvenile prostitutes use condoms? The answer lies partly with their clients. Prostitutes who did ask clients to wear a condom generally found that clients would refuse to do so. Rather than lose her client, the girl rarely pressed the point, or, if she did, frequently reported that she was beaten into submission. Given the above situation, a number of interventions would seem to be required:

(a) Unwanted pregnancies and sexually transmitted diseases can be greatly reduced with consistent condom use. This can be promoted by their widespread availability coupled with adequate information on how to use them and the importance of doing so. The author was involved in such a programme, with staff from Save the Children USA and with the co-operation of Population Services International. A leaflet advertising a series of "festivals" for street girls was widely disseminated amongst this population. At these gatherings girls were provided with food, music and dancing, as well as talks from other street girls about the importance of condom use. PSI made available a large number of free condoms. Projects of this kind should be replicated by NGOs working with this population.

(b) The above intervention needs to be coupled with messages which are aimed directly at the male clients of prostitutes. The efficacy of radio as a means of public education is illustrated by the widespread knowledge of Aids amongst street children. This medium should be employed to highlight the enormous incidence of HIV amongst prostitutes in Addis Ababa and the risks of unprotected intercourse. 
We have seen above that a basic sheltered accommodation service would greatly improve the quality of life of many homeless children. However, such services are not sufficient in themselves for one small category of street children - mothers. Street life is extremely harsh for young infants. Consequently street infants experience a high mortality rate. Street mothers and their infants require a comprehensive intervention programme, one that meets basic needs such as shelter, food, health care and clothing, but one that also meets their educational and vocational needs. Unfortunately, the only such programme of this kind in Addis Ababa did not stay open for very long. It is a large and expensive commitment for any one agency. However, agencies working with street children need to scrutinise their criteria for selecting beneficiaries. Are NGOs avoiding, or "selecting out", populations which are difficult to work with such as pregnant girls, mothers, Aids victims and aggressive older youths? Who shall cater for the needs of such groups?

An unknown number of adolescent girls leave their rural homes to work as poorly paid maids in Addis Ababa. Due to mistreatment such as under-feeding, overworking, withholding of payment and sexual assaults, it was from these jobs that many girls left to come to the streets. Little is known about these girls and their work conditions. As they are a "invisible" group, they have not attracted the attention of researchers or NGOs. A separate investigation is required to determine the extent of mistreatment experienced by the large numbers of maids in Addis Ababa and to recommend strategies which will discourage them from coming to the streets. 
Because of war, famine, civil unrest, inaccessibility and a minimal infrastructure, Ethiopia's tourism industry is embryonic. However, the highly visible nature of prostitution in Addis Ababa is already attracting men from neighbouring states and from the city's extensive diplomatic and NGO population (the OAU is head quartered in Addis Ababa). Whilst the majority of clients of Ethiopian juvenile prostitutes are Ethiopian, the potential for more extensive exploitation by foreigners exists. In order to suppress such a development the active pursuit, in law, of the clients of juvenile prostitutes is required. Perhaps the legislative changes mentioned at the beginning of this article would be appropriate. Unfortunately, the issue of widespread juvenile prostitution is a relatively low priority in what is one of the world's poorest countries. Nevertheless, the extremely high human costs paid by juvenile prostitutes should be recognised and steps taken to ensure that a "sex-tourism" industry as exists in other developing countries does not become established.

Most juveniles involved in prostitution have initially attempted to survive by means of other work (Baardson, 1993, p. 26). Furthermore, their involvement in prostitution is frequently part-time (Lalor, 1997a). That is to say, involvement in prostitution is a measure of last resort. Should alternative sources of income be provided, initiation into prostitution may be stemmed. However, Addis Ababa has many income generation schemes for various impoverished groups. It is difficult to find a market for the ubiquitous leather trinkets and woven baskets. Less directed initiatives, such as small business loans, or neighbourhood credit schemes give participants the opportunity to identify and develop their own income generating projects as an alternative to prostitution. 


\section{CONCLUSION}

Juvenile prostitution in Addis Ababa is fostered by the conditions of extreme deprivation which young adolescent street girls find themselves in. Prostitution has greater earning potential than almost any other avenue open to such girls. However, the price paid in sexual assaults, beatings, theft, unwanted pregnancies, illness and exposure to sexually transmitted disease is high.

\section{BIBLIOGRAPHY}

Agnelli, S. (1986). Street children: A growing urban tragedy. London: Weinfield and Nicolson.

Baardson, P. (1993), Child prostitution in Addis Ababa. Addis Ababa: Unpublished Radda Barnen report.

Bracey, D.H. (1979), Baby-pros: Preliminary profiles of juvenile prostitutes. New York: John Jay Press.

Enablers (1978). Juvenile prostitution in Minnesota: The report of a research project. St. Paul: The Enablers.

Ennew, J. (1986), The sexual exploitation of children. Cambridge: Polity Press.

Gibson-Ainyette, I, Templer, D., Brown, R. And Veaco, L. (1988) 'Adolescent female prostitutes', Archives of Sexual Behavior 17(5): 431-8.

Ireland, K. (1993), Wish you weren't here. The sexual exploitation of children and the connection with tourism and international travel. London: Save the Children.

James, J. (1980), Entrance into juvenile prostitution. Washington D.C.: National Institute of Mental Health. 
Lalor, K. (1997a), Victimisation of street children in Addis Ababa: Factors of resilience and susceptibility. Unpublished Ph.D. thesis: University College Cork, Ireland.

Lalor, K. (1997b) 'Researching the victimisation of street children in Addis Ababa: Methodological issues', in Proceedings of the Conference 'Researching Children's Experiences: Qualitative Approaches'. Trinity College Dublin: The Children's Centre.

Lalor, K. (forthcoming) 'Street children: A comparative perspective', Child Abuse and Neglect.

Lucchini, R. (1994), The street girl: prostitution, family and drugs. University of Fribourg, Switzerland: Institute for Economics and Social Sciences, Working paper No. 243.

Mehret, M., Khodakevich, L., Shanko, B. \& Belete, F. (1990) 'Sexual behaviours and some social features of female sex workers in the city of Addis Ababa', Ethiopian Journal of Health Development 4(2): 133-7.

Muntarbhorn, V. (1992) Rights of the child: sale of children. Report of the special Rapporteur appointed in accordance with Commission of Human Rights resolution 1990/68-E/CN/1992/55.

Nyland, B. (1995) 'Child prostitution and the new Australian legislation on paedophiles in Asia', Journal of Contemporary Asia 25(4): 546-60.

O’Connell Davidson, J. \& Sachez Taylor, J. (1996) 'Child prostitution and tourism: beyond the stereotypes', In J. Pilcher \& S. Wagg (Eds) Thatcher's children. London: Falmer.

O’ Grady, R. (1993) 'Sexually exploited children: receivers and transmitters of HIV', Children Worldwide 20(2): 43. 
Seng, M.J. (1989), 'Child sexual abuse and adolescent prostitution: a comparative analysis', Adolescence 24(95): 665-75.

Silbert, M.H. (1980) Sexual assault of prostitutes: Phase one. Washington D.C.: National Institute of Mental Health.

Taçon, P. (1992). Marco and the malevolent monsters. Unpublished paper for presentation to the Organisation of African Unity.

Truong, Thanh-dam (1990) Sex, money and morality. Prostitution and tourism in Southeast Asia. London: Zed Books Ltd.

Weisberg, D.K. (1985) Children of the night: A study of adolescent prostitution. Lexington, Mass.: Lexington Books. 


\begin{abstract}
Title: The Victimisation of Juvenile Prostitutes in Ethiopia.

This paper quantifies the victimisation experienced by 30 juvenile prostitutes in Addis Ababa, Ethiopia. Seventy three per cent had been raped at least once and ninety three per cent had been beaten in the course of their work. Only $50 \%$ used contraception, resulting in a pregnancy rate of $37 \%$. Findings indicate that prostitution is a highly victimogenic lifestyle, fostered by conditions of extreme deprivation. Policy and practice implications are discussed.
\end{abstract}


